\title{
Escherichia coli Specific Virulence-Gene Markers Analysis for Quality Control of Ovine Cheese in Slovakia
}

\author{
Dobroslava Bujňáková *(D), Lívia Karahutová (D) and Vladimír Kmet' \\ Centre of Biosciences of the Slovak Academy of Sciences, Institute of Animal Physiology, 04001 Košice, Slovakia; \\ karahutova@saske.sk (L.K.); kmetv@saske.sk (V.K.) \\ * Correspondence: dbujnak@saske.sk
}

Citation: Bujňáková, D.; Karahutová,

L.; Kmet', V. Escherichia coli Specific

Virulence-Gene Markers Analysis for Quality Control of Ovine Cheese in

Slovakia. Microorganisms 2021, 9, 1808 . https://doi.org/10.3390/

microorganisms 9091808

Academic Editor: Sangryeol Ryu

Received: 23 July 2021

Accepted: 24 August 2021

Published: 25 August 2021

Publisher's Note: MDPI stays neutral with regard to jurisdictional claims in published maps and institutional affiliations.

\begin{abstract}
Shiga toxin-producing and extra-intestinal pathogenic Escherichia coli (E. coli) have the potential to spread through faecal waste, resulting in contamination of food and causing foodborne disease outbreaks. With the aim of characterizing unpasteurized ovine cheese in Slovakia, a total of 92 E. coli strains were examined for eleven representative virulence genes typical for (extra-)intestinal pathogenic E. coli and phylogenetic grouping. Phylogenetic groups B1 (36\%) and A (32\%) were the most dominant, followed by groups $\mathrm{C}(14 \%)$ and $\mathrm{D}(13 \%)$, while the lowest incidence was recorded for $\mathrm{F}(4 \%)$, and $\mathrm{E}(1 \%)$, and $43(47 \%)$ samples carried at least one virulent gene, i.e., potential pathogens. Isolates present in groups $\mathrm{E}, \mathrm{F}$ and D showed higher presence of virulence genes $(100 \%, 75 \%$, and $67 \%$ ), versus $55 \%, 39 \%$, and $28 \%$ in commensal B1, C, and A, respectively. Occurrence of pap C and fyuA (both $24 \%$ ) was highest, followed by tsh, iss, st $x 2$, cnf1, kpsII, cvaC, st $x 1$, iut A and eaeA. Nine E. coli strains (almost $10 \%$ of all tested and around $21 \%$ of our virulence-gene-associated isolates) harboured st $x 1$, st $x 2$ or eae. Ovine cheeses in Slovakia are highly contaminated with E. coli including potentially pathogenic strains capable of causing intestinal and/or extra-intestinal diseases, and thus may pose a threat to public health while unpasteurized.
\end{abstract}

Keywords: ExPEC; STEC; pathogenic potential; phylogenetic grouping; PCR

\section{Introduction}

Public health hazards associated with consumption of unpasteurized milk products, including related foodborne disease outbreaks, have been reported in parts of the world [1,2], and consequently strict control of the microbial quality of these types of food is required.

Dairy products can be contaminated with various bacteria. Among the pathogenic agents, Listeria monocytogenes, Salmonella spp., Shiga toxin-producing E. coli (STEC) serotype O157:H7 and enterotoxin-producing Staphylococcus aureus are most involved in foodborne outbreaks related to the consumption of raw milk cheese in industrialized countries [3]. These foodborne pathogens usually cause illness with acute symptoms restricted to the gastrointestinal tract. However, in some cases, they can cause serious extra-intestinal diseases such as Hemolytic Uremic Syndrome (HUS) associated with E. coli O157:H7 [4].

The authors Cancino-Padilla et al. [5] compiled a summary of outbreaks associated with the consumption of various dairy products in the world. Several outbreaks have been associated with the consumption of cheese and other ready to-eat foods concerning their main contaminant $E$. coli stemming from faecal or farm environmental contamination during the milking process $[6,7]$.

The presence of $E$. coli as a reliable indicator of direct or indirect poisoning testifies not only to poor hygienic practices but also (and worse) it can be a source of virulence genes rendering the bacteria pathogenic with the ability to cause a variety of sicknesses. E. coli associated with animal or human diseases are divided into two major groups, intestinal and extra-intestinal, and based on their virulence properties into several subgroups (intestinal: enteropathogenic E. coli (EPEC), enterohemorrhagic E. coli (EHEC) or Shiga 
toxin-producing E. coli (STEC), enterotoxigenic E. coli (ETEC), enteroinvasive E. coli (EIEC), enteroaggregative E. coli (EAEC), and diffusely adherent E. coli (DAEC); extra-intestinal: uropathogenic E. coli (UPEC), avian pathogenic E. coli (APEC), meningitis-associated E. coli (MNEC) and necrotoxigenic E. coli (NTEC)) [8]. Moreover, virulence-hybrid E. coli isolates have also been reported $[9,10]$.

Virulence factors (VF) related to the pathogenicity of various subtypes of E. coli are numerous and have a wide range of activity, from those enabled for bacteria colonization to those causing virulence, including adhesins, toxins, iron acquisition factors and polysaccharide capsules, which are usually encoded on pathogenicity islands (PAIs), plasmids and other mobile genetic elements. The most important PAI in Enterobacterales is High Pathogenicity Island, encoded primarily in the iron-uptake system essential for enhancing bacterial condition, the so-called "fitness cost". Iron uptake as an important survival factor, along with resistance and virulence, allows bacteria to establish in a competitive environment [11].

Since healthy adult cattle and sheep are an asymptomatic reservoir of STEC, faecal contaminating E. coli strains isolated from milk and dairy products often contain high prevalence of Vero or Shiga-toxins (vtx1 and $v t x 2$ or st $x 1$ and st $x 2)$, intimin (eaeA) and hemolysin $(h l y A)$. These factors can cause bacterial adhesion and invasion into the intestinal epithelial cells, causing severe attaching-effacing (A/E) lesions. Certain STEC occurrence in raw milk, in the particular serotype O157:H7, is well documented and represents a concern since up to $10 \%$ of people infected with these bacteria develop HUS, which is potentially a lethal condition, especially in children, immune-deficient and elderly people [12,13]. In 2018, EFSA (European Food Safety Authority) reported a total of 5079 foodborne outbreaks of which 14, involving 775 people, were linked to cheese consumption, and the most common causative agents were STEC and bacterial toxins [14]. The results obtained so far point to the importance of food vehicles in the diffusion of STEC infections at the EU level. Analysis of the virulence gene profiles of the isolated STEC strains highlights the presence of STEC in food with potential for causing severe disease. EFSA recommends reporting on the STEC virulence genes as their analysis represents the basis for molecular risk assessment and the most valuable tool for predicting that risk and the severity of STEC infections in humans.

In recent years, investigators have hypothesized that food, including unpasteurized milk products, can be a reservoir for many other virulence factors responsible for extraintestinal infections, and can play a major role in the transmission of ExPEC (Extraintestinal pathogenic Escherichia coli) strains $[2,15,16]$. Although research has been ongoing for many years, specific criteria for classifying E. coli strains such as ExPEC have not so far been established. According to results obtained by Johnson and Russo [17], ExPEC were defined as $E$. coli isolates containing two or more virulence markers, which were identified by means of multiplex PCR reaction, including papA genes (a structural subunit of P-fimbriae) and/or papC (P fimbriae), sfa/foc (S and F1C fimbriae subunits), afa/dra (adhesins binding antigen Dr), kpsMT II (group 2 capsular polysaccharides) and iutA (aerobactin receptor) [18]. However, for many bacterial pathogens infecting mucosal tissues, expression of only one specific adhesin is critical and sufficient for pathogenesis. Disruption of the ability of a bacterial pathogen to attach and to colonize a specific tissue by adhesin-mediated receptor recognition is often enough to make it avirulent [2].

Bearing in mind that the possibility of transmission of various pathogenic intestinal and extra-intestinal E. coli strains to humans, causing diseases through consumption of raw milk as well as raw milk products, has been reported worldwide $[19,20]$, monitoring not only of $E$. coli presence, but also their pathogenic potential through virulence genes occurrence, becomes a significant necessity. With regard to this development and due to the paucity of data on the microbial contamination of cheese, mainly concerning virulenceassociated genes and phylogenetic distribution in Slovakia, we examined 92 E. coli isolates from unpasteurized ovine cheeses for possession of traits associated with the virulence of human extra-intestinal pathogenic E. coli (ExPEC) or intestinal Vero (Shiga) toxin (Vtx or 
Stx)-producing E. coli (VTEC or STEC): e.g., iutA, iss, cvaC, kpsII, tsh, papC, fyuA, cnf1, stx1, stx2, eae $A$ and phylogenetic grouping.

\section{Materials and Methods}

\subsection{Source of Samples and Isolation}

During the course of one year (August 2018-August 2019), 92 samples of ovine cheese were obtained from local farmers in western Slovakia. The samples were collected in sterile sample collection bags transferred to the laboratory in a cool-box. All cheese samples showed normal physical character including consistency, odour and colour. Ten grams of each cheese sample were homogenized in a Stomacher (BioTech, Prague, Czech Republic) with $90 \mathrm{~mL}$ of sterile buffered peptone water (Oxoid, Basingstoke, UK). After preparing the 1:10 dilution, samples were streaked onto Mac Conkey Agar (Oxoid, Basingstoke, UK) and UriSelect Agar (Bio-Rad Laboratories, Hercules, CA, USA) overnight at $37^{\circ} \mathrm{C}$. The typical colonies on both agars were isolated, identified and confirmed as E. coli using MALDI-TOF MS biotyper (Bruker Daltonics, Bremen, Germany) [21] and ENTEROtest24 (Erba Lachema Brno, Czech Republic). A single colony of E. coli was isolated from each sample.

\subsection{DNA Preparation}

The cultures were inoculated on Nutrient Agar (Oxoid, Basingstoke, UK) and incubated at $37^{\circ} \mathrm{C}$ for $24 \mathrm{~h}$. A bacteriological loop was used to carry part of the colony into $100 \mu \mathrm{L}$ distilled water, which was then vortexed, boiled for $10 \mathrm{~min}$ and centrifuged for 2 $\min$ at $12,000 \times g$, and the supernatant was used for PCR.

\subsection{Phylogenetic Groups}

All isolates were assigned to phylogenetic groups (A, B1, C, B2, D, E and F) based on Clermont phylogenetic typing schemes [22]. The protocols are based on amplification of $\operatorname{chuA}, y j a A$, arpA, TspE4.C2 DNA fragments and additional testing for specific genes in the $\mathrm{E}(\operatorname{arp} A g p E)$ and $\mathrm{C}(\operatorname{trp} A g p C)$ groups. Classification of the strains was performed based on the presence or absence of genes.

\subsection{Genes of Virulence Factors}

All isolates were subjected to a multiplex and/or single PCR analysis for detection genes associated with ExPEC, specifically: iutA-receptor for aerobactin, cvaC-colicin V, $k p$ sII-capsular polysialic acid virulence factor, iss-increased serum survival, tsh-temperature sensitive haemagglutinin, papC-P fimbrial adhesin and fyuA-yersiniabactin receptor for ferric yersiniabactin uptake. Moreover, we used genes encoding Shiga-toxin types 1, 2 (stx1, st $x 2)$, cytotoxic necrotizing factor (CNF1) and the gene encoding intimin for attaching and effacing mechanisms (eaeA). PCR primers, length of their amplified products, annealing and references are listed in Table 1 . The amplifications were carried out in a single tube with a volume of $25 \mu \mathrm{L}$, utilizing TaqI polymerase (Solis Biodyne, Tartu, Estonia). Amplified products were run on $1.5 \%$ agarose gel.

Table 1. PCR primers, length of the amplified products, annealing and references.

\begin{tabular}{|c|c|c|c|c|}
\hline Gene & Primer Sequence $\left(5^{\prime} 3^{\prime}\right)$ & Product & $T_{\text {ann }}$ & Reference \\
\hline $\operatorname{arp} A$ & $\begin{array}{l}\text { AACGCTATTCGCCAGCTTGC } \\
\text { TCTCCCCATACCGTACGCTA }\end{array}$ & $400 \mathrm{bp}$ & $59^{\circ} \mathrm{C}$ & [22] \\
\hline chuA & $\begin{array}{l}\text { ATGGTACCGGACGAACCAAC } \\
\text { TGCCGCCAGTACCAAAGACA }\end{array}$ & $288 \mathrm{bp}$ & $59^{\circ} \mathrm{C}$ & [22] \\
\hline yjaA & $\begin{array}{l}\text { CAAACGTGAAGTGTCAGGAG } \\
\text { AATGCGTTCCTCAACCTGTG }\end{array}$ & $211 \mathrm{bp}$ & $59^{\circ} \mathrm{C}$ & [22] \\
\hline tspE4.C4 & $\begin{array}{l}\text { CACTATTCGTAAGGTCATCC } \\
\text { AGTTTATCGCTGCGGGTCGC }\end{array}$ & $152 \mathrm{bp}$ & $59^{\circ} \mathrm{C}$ & [22] \\
\hline
\end{tabular}


Table 1. Cont.

\begin{tabular}{|c|c|c|c|c|}
\hline Gene & Primer Sequence $\left(5^{\prime} 3^{\prime}\right)$ & Product & $T_{\text {ann }}$ & Reference \\
\hline ArpAgpE.f & $\begin{array}{c}\text { GATTCCATCTTGTCAAAATATGCC } \\
\text { GAAAAGAAAAAGAATTCCCAAGAG }\end{array}$ & $301 \mathrm{bp}$ & $57^{\circ} \mathrm{C}$ & [23] \\
\hline $\operatorname{trp} A g p C .1$ & $\begin{array}{l}\text { AGTTTTATGCCCAGTGCGAG } \\
\text { TCTGCGCCGGTCACGCCC }\end{array}$ & $219 \mathrm{bp}$ & $59^{\circ} \mathrm{C}$ & [23] \\
\hline kps II & $\begin{array}{c}\text { GCGCATTTGCTGATACTGTTG } \\
\text { CATCCAGACGATAAGCATGAGCA }\end{array}$ & $272 \mathrm{bp}$ & $63{ }^{\circ} \mathrm{C}$ & [24] \\
\hline iss & $\begin{array}{c}\text { ATCACATAGGATTCTGCCG } \\
\text { ACAAAAAGTTCTATCGCTTCC }\end{array}$ & $700 \mathrm{bp}$ & $61^{\circ} \mathrm{C}$ & [25] \\
\hline papC & $\begin{array}{l}\text { GACGGCTGTACTGCAGGGTGTGGCG } \\
\text { ATATCCTTTCTGCAGGGATGCAATA }\end{array}$ & $328 \mathrm{bp}$ & $61^{\circ} \mathrm{C}$ & [26] \\
\hline $\operatorname{coaC}$ & $\begin{array}{l}\text { CACACACAAACGGGAGCTGTT } \\
\text { CACACACAAACGGGAGCTGTT }\end{array}$ & $680 \mathrm{bp}$ & $63^{\circ} \mathrm{C}$ & [24] \\
\hline tsh & $\begin{array}{l}\text { GGTGGTGCACTGGAGTGG } \\
\text { AGTCCAGCGTGATAGTGG }\end{array}$ & $620 \mathrm{bp}$ & $55^{\circ} \mathrm{C}$ & [27] \\
\hline iut $A$ & $\begin{array}{l}\text { GGCTGGACATGGGAACTGG } \\
\text { CGTCGGGAACGGGTAGAATCG }\end{array}$ & $300 \mathrm{bp}$ & $63^{\circ} \mathrm{C}$ & [24] \\
\hline fyuA & $\begin{array}{l}\text { TGATTAACCCCGCGACGGGAA } \\
\text { CGCAGTAGGCACGATGTTGTA }\end{array}$ & $880 \mathrm{bp}$ & $55^{\circ} \mathrm{C}$ & [24] \\
\hline stx 1 & $\begin{array}{l}\text { ACGTTACAGCGTGTTGCRGGGATC } \\
\text { TTGCCACAGACTGCGTCAGTRAGG }\end{array}$ & $121 \mathrm{bp}$ & $63^{\circ} \mathrm{C}$ & [28] \\
\hline stx 2 & $\begin{array}{l}\text { TGTGGCTGGGTTCGTTAATACGGC } \\
\text { TCCGTTGTCATGGAAACCGTTGTC }\end{array}$ & $102 \mathrm{bp}$ & $63^{\circ} \mathrm{C}$ & [28] \\
\hline eaeA & $\begin{array}{l}\text { TGAGCGGCTGGCATGAGTCATAC } \\
\text { TCGATCCCCATCGTCACCAGAGG }\end{array}$ & $241 \mathrm{bp}$ & $63^{\circ} \mathrm{C}$ & [28] \\
\hline cnf1 & $\begin{array}{l}\text { GGCGACAAATGCAGTATTGCTTGG } \\
\text { GACGTTGGTTGCGGTAATTTTGGG }\end{array}$ & $552 \mathrm{bp}$ & $63^{\circ} \mathrm{C}$ & [28] \\
\hline
\end{tabular}

\section{Results}

\subsection{Phylogenetic Grouping}

Phylogenetic grouping of $92 \mathrm{E}$. coli isolates from unpasteurized cheese showed that $33(35.87 \%), 29(31.52 \%)$, and $13(14.13 \%)$ belonged in phylogenetic groups B1, A, and C respectively, as shown in Table 2, and these were followed by group D (12 isolates; $13.04 \%$ ). Finally, groups $\mathrm{E}$ and $\mathrm{F}$ were less prevalent with $1.09 \%$ (1 isolate) and $4.35 \%$ (4 isolates), while group B2 was not detected.

Table 2. Phylogenetic distribution of E. coli from unpasteurized cheese.

\begin{tabular}{|c|c|c|c|c|c|c|c|c|}
\hline \multirow[b]{2}{*}{$\begin{array}{c}\text { Phylogenetic } \\
\text { Groups }\end{array}$} & \multirow{2}{*}{$\begin{array}{l}\text { No. of Isolates } / \% \text { of } \\
\text { Occurrence } \\
(n=92)\end{array}$} & \multirow{2}{*}{$\begin{array}{l}\text { Distribution } \\
\text { According to Gene } \\
\text { Groupings }(n)\end{array}$} & \multicolumn{6}{|c|}{ Quadruplex Genotype and Next Step for C or E Phylogroup } \\
\hline & & & $\operatorname{arp} A$ & chuA & yjaA & TspE4.C4 & $\begin{array}{l}\text { ArpA for } \\
\text { E Group }\end{array}$ & $\begin{array}{l}\operatorname{trp} A \text { for } C \\
\text { Group }\end{array}$ \\
\hline \multirow{2}{*}{ Group A/C } & \multirow{2}{*}{$29 /(32 \%)$} & 12 & + & & & & & \\
\hline & & 17 & + & & + & & & - \\
\hline Group C & $13 /(14 \%)$ & 13 & + & & + & & & + \\
\hline Group B1 & $33 /(36 \%)$ & 33 & + & & & + & & \\
\hline \multirow{2}{*}{ Group D/E } & \multirow{2}{*}{$12 /(13 \%)$} & 8 & + & + & & \multirow[t]{2}{*}{+} & - & \\
\hline & & 4 & + & + & & & - & \\
\hline Group E & $1 /(1 \%)$ & 1 & + & + & + & & + & \\
\hline Group F & $4 /(4 \%)$ & 4 & & + & & & & \\
\hline
\end{tabular}


Phylogenetic groups B1 and A were predominant among the tested isolates. It is interesting to note that $54.6 \%(18 / 33)$ of isolates belonging in group B1 as well as $100 \%$ $(1 / 1), 75 \%(3 / 4)$ and $66.6 \%(8 / 12)$ of isolates belonging in groups $\mathrm{E}, \mathrm{F}$ and $\mathrm{D}$ respectively, were found to have at least one of the examined virulence genes (four isolates contained three virulence genes-iss, cvaC, papC - group B1; iss, iutA, cnf1- group D; stx1, stx2, cnf1-group B1 and iss, cvaC, cnf1-group C) (Tables 3 and 4).

Table 3. The percentage of occurrence of virulence-related genes in various phylogenetic groups of $E$. coli.

\begin{tabular}{|c|c|c|c|c|c|c|c|c|c|c|c|c|}
\hline \multirow{2}{*}{$\begin{array}{l}\text { Phylogenetic } \\
\text { Groups }\end{array}$} & \multirow{2}{*}{$\begin{array}{l}\text { No. of Isolates/No. with Virulence Genes } \\
\text { (\% Virulent Strains) }\end{array}$} & \multicolumn{11}{|c|}{ Presence of Virulence Genes } \\
\hline & & iss & $c v a C$ & papC & iutA & tsh & fyuA & $k p s I I$ & stx1 & $s t x 2$ & eaeA & cnf1 \\
\hline Group A & $29 / 8(27.6 \%)$ & & & 1 & & 1 & 4 & 2 & & 2 & & \\
\hline Group B1 & $33 / 18(54.6 \%)$ & 4 & 3 & 5 & 1 & 6 & 3 & & 2 & 3 & & 2 \\
\hline Group C & $13 / 5(38.5 \%)$ & 1 & 1 & 2 & & 1 & 1 & & & 1 & & 2 \\
\hline Group D & $12 / 8(66.6 \%)$ & 1 & & 2 & 1 & 2 & 1 & 2 & 1 & & & 2 \\
\hline Group E & $1 / 1(100 \%)$ & & & & & & & & & & 1 & \\
\hline Group F & $4 / 3(75 \%)$ & 1 & & 1 & & & 2 & 1 & & & & \\
\hline TOTAL & $92 / 43(46.7 \%)$ & 7 & 4 & 11 & 2 & 10 & 11 & 5 & 3 & 6 & 1 & 6 \\
\hline
\end{tabular}

Table 4. Presence of virulence gene patterns in E. coli.

\begin{tabular}{|c|c|c|}
\hline No. of Genes & Virulence Genes & No. of Isolates $(n=92)$ \\
\hline 1 & iss & 1 \\
\hline 1 & $c v a C$ & 1 \\
\hline 1 & papC & 5 \\
\hline 1 & iut $A$ & 1 \\
\hline 1 & tsh & 6 \\
\hline 1 & fyuA & 6 \\
\hline 2 & fyuA, cnf 1 & 1 \\
\hline 1 & chf1 & 1 \\
\hline 1 & kpsII & 2 \\
\hline 3 & iss, cvaC, cnf 1 & 1 \\
\hline 2 & iss, papC & 1 \\
\hline 2 & iss, cnf 1 & 1 \\
\hline 3 & iss, iut $A$, cnf1 & 1 \\
\hline 2 & iss, fyuA & 1 \\
\hline 3 & iss, cvaC, papC & 1 \\
\hline 2 & tsh, fyuA & 1 \\
\hline 2 & tsh, kpsII & 1 \\
\hline 2 & tsh, st $x 2$ & 2 \\
\hline 2 & papC, cvaC & 1 \\
\hline 2 & papC, kpsII & 1 \\
\hline 2 & papC, stx1 & 1 \\
\hline 2 & papC, stx2 & 1 \\
\hline 2 & fyuA, kpsII & 1 \\
\hline 2 & fyuA, stx2 & 1 \\
\hline
\end{tabular}


Table 4. Cont.

\begin{tabular}{ccc}
\hline No. of Genes & Virulence Genes & No. of Isolates $(\boldsymbol{n}=\mathbf{9 2})$ \\
\hline 1 & $e a e A$ & 1 \\
\hline 1 & $s t x 1$ & 1 \\
\hline 1 & stx 2 & 1 \\
\hline 3 & stx 1, st $x 2$, cnf 1 & 1 \\
\hline 0 & No gene & 49 \\
\hline
\end{tabular}

\subsection{The Occurrence of E. coli and Virulence Genes in Unpasteurized Cheese}

All 92 samples of ovine cheese collected from various locations in western Slovakia were contaminated with $E$. coli. Isolates were investigated for the presence of 11 virulence genes usually present in pathogenic $E$. coli. The occurrence of potentially pathogenic $E$. coli (which carried one or more of the targeted virulence genes) was $47 \%(n=43)$. The remaining $49(53 \%)$ isolates were negative. Isolates present in groups E, F and D showed the highest presence of virulence genes $(100 \%, 75 \%$ and $67 \%$ respectively); however phylogenetic groups considered as commensal, i.e., B1, C and A, also had a high incidence of virulence genes $(55 \%, 39 \%$ and $28 \%$ respectively). It was found that the most prevalent genes among 43 isolates with virulence factors were papC and fyuA detected in 11 isolates (both $51 \%$ ), while $10(23 \%), 7(16 \%), 6(14 \%), 6(14 \%), 5(12 \%), 4(9 \%), 3(7 \%), 2(4.6 \%)$ and $1(2.3 \%)$ isolates were positive for tsh, iss, stx2, cnf1, kpsII, cvaC, stx1, iut $A$ and eae A genes, respectively (Table 3).

Based on the distribution of the various virulence genes investigated, all the tested isolates exhibited 28 different virulence gene patterns. Four isolates were positive for three targeted virulence genes, 14 showed presence of two genes, and in 26 others one gene was detected.

The three most prevalent patterns consisted of isolates possessing one virulence gene, fyuA, tsh, or papC ( $n=6, n=6, n=6$ and $n=5$ respectively). Based on the distribution of verotoxines and intimin, nine of the tested isolates exhibited a positive signal for one of those genes. Specifically, five isolates harbored clinically and epidemiologically the most important st $x 2$ alone, two only st $x 1$, and one strain featured both stx 1 and stx 2 genes together with gene cnf1. The gene encoding cytotoxic necrotizing factor (CNF1) was detected in six isolates. Only one of the isolates was positive for eae, which could be classified as EPEC defined as Stx-negative E. coli able to produce A/E lesions on intestinal cells. Detailed results are shown in Table 4.

\section{Discussion}

Foodborne diseases caused by various bacterial pathogens are a significant global public health concern. Based on the above, the EU has recently strengthened the rules for strict control of food safety and public health to cope with the spread of certain infectious diseases.

The presence of $E$. coli in milk and milk products is an important indicator of faecal or environmental contamination and poor hygienic practices. Conventional microbiological diagnostics in food control include only determination of E. coli numbers per gram without any other characterization of isolated strains.

In addition to the presence of E. coli denoting faecal contamination, the presence of virulence-related genes in E. coli strains refers to the pathogenicity of the isolates. Previous studies documented the equation of some $E$. coli isolates from raw milk and products for virulence markers $[2,19,29]$. Considering the above, the present study thus aimed to assess raw cheese quality by capturing live $E$. coli and investigating the $E$. coli isolates for certain functioning virulence-associated genes using PCR assay.

Based on our results it is clear that single or double virulence factors were demonstrated in the majority of examined isolates. One isolate carried two virulence factors papC 
and kpsII, which were described by Johnson and Russo [17] as ExPEC, but the importance of this remains irrelevant regarding the possibility of the presence of other markers, which were not the subject of this study.

In our project, every sample of the 92 cheeses was contaminated with E. coli. A similar high prevalence of E. coli in cheese has also been reported in Brazil (96-97.7\%) [20]. Altogether, $47 \%$ (43/92) of the investigated dairy products carried potentially pathogenic E. coli (possessing one or more of the virulence genes tested), as shown in Table 3.

When interpreting the results, keep in mind that the data of the various diagnostic procedures are not directly comparable due to differences in strategy sampling and analytical application method. Our approach used for selecting the colonies forming the dataset was based on the selection of only a single colony from every sample. A different approach was used by Skočková et al. [30] for monitoring of the occurrence of STEC in swabs from the carcasses of pigs and cattle at slaughterhouses in the Czech Republic. After homogenization and incubation, $1 \mathrm{~mL}$ of bacterial suspension was used for DNA isolation, and after PCR, st $x$-positive samples were inoculated on selective media, incubated overnight and up to 50 colonies from one sample with $E$. coli morphology were investigated for the presence of st $x$ and eaeA genes. Their results showed the prevalence of STEC in cattle (3.9\%) and pig (5.1\%) carcasses in the Czech Republic, although raw meat has not been considered an important source of STEC.

From our results concerning stx and eae, nine E. coli strains (almost $10 \%$ of all tested and around $21 \%$ of our virulence gene-associated isolates) harboured st $x 1$, stx 2 or eae (Table 4). Of these, five contained st $x 2$ alone, and as described by Friedrich et al. [31], st $x 2$ is clinically and epidemiologically the most important Shiga-toxin type, and the probability of HUS development in infections from strains harbouring st 2 is higher than that from strains containing either st $x 1$ or both st $x 1$ and st $x 2$. Healthy sheep are asymptomatic reservoirs of STEC and thus faecal contamination during milk processing explains the occurrence of these bacteria in dairy products, and this is a significant problem not only for fresh cheese, but also for hard ripened cheeses, because of the ability of STEC to survive during the production procedure with periods of maturation.

In the period 2012-2017, a total of 330 STEC outbreaks were reported in 18 countries of the European Union, involving 2841 cases, 463 hospitalizations and five fatalities. Of all these outbreaks reported, the food vehicle was identified for 164 outbreaks (49.7\%) and five outbreaks by strength of evidence of identification of food vehicle were reported from Slovakia and Poland [32]. In 2018, STEC diseases were the fourth most common zoonosis in Europe.

The report on zoonosis in Slovakia indicates, that in 2016, from 46 examined food samples (cheeses from unpasteurized milk, meat products), STECs were confirmed in $28.26 \%$. A year later, twenty-six foods were examined with only one being STEC-positive. Reports from the following years (2018-2020) did not contain data on the STEC situation in Slovakia (https: / / www.mpsr.sk/?navID=47\&sID=111\&navID2=506, accessed on 12 December 2016).

Other important virulence determinants include the locus of enterocyte effacement (LEE) shared by EPEC. This $35-45 \mathrm{~kb}$ pathogenicity island is responsible for the formation of attaching and effacing (A/E) lesions on intestinal epithelial cells. It contains the eae $A$ gene encoding the outer membrane adhesin, intimin, which mediates tight contact between STEC or EPEC and intestinal epithelial cells. The eaeA gene is a well-known virulence factor not only for EPEC and EHEC but also atypical EPEC, in which the eaeA gene occurs alone without the presence of adherence factor plasmid $(p E A F)$ genes [8]. Our study identified the eae $A$ gene in one isolate (2.3\%) (Tables 3 and 4 ), which could be classified as EPEC, defined as a St $x$-negative $E$. coli strain able to produce A/E lesions on intestinal cells, detectable in vitro by means of positive eae PCR testing. Our result showing the occurrence of the eae gene is in agreement with several previous studies: 9.1\% in Saudi Arabia [19], 3.1\% in Slovakia [29] and 0.9\% in Egypt [2]. 
Since none of our strains carried stx and eae together, the strains would not have to be able to adhere to the cells and produce Shiga toxins. However, the EFSA Journal [32] notes, inter alia, that the presence of intimin (eae gene) was an aggravating factor, but this virulence factor was not always essential for severe illness, suggesting that there is an alternative mechanism of attachment. As an example, during 2011, a large outbreak caused by an unusual E. coli strain was reported in Germany. The pathotype combined the virulence potential of STEC and enteroaggregative E. coli. The aggregative adherence fimbriae colonization mechanism substituted for the locus of enterocyte effacement functions normally encoded by the eae gene in EHEC strains. Clinical presentation of the infection also included bloody diarrhea and HUS [33]. The Cytotoxic Necrotizing Factor (CNF1) [28] is a bacterial virulence factor associated with ExPEC strains causing urinary tract infection and meningitis that induces a drastic rebuilding of the microfilamental network on various eukaryotic cells in culture into thick stress fibers. The $c n f 1$ was detected in six (6.5\%) of all tested and around $14 \%$ of our virulence-gene-associated isolates. The incidence of the $c n f 1$ virulence marker in E. coli strains isolated from traditional Slovak ovine cheese was also described by Holko et al. [29], and cnf1 was confirmed in 3 isolates from 95 (3\%) examined overall.

Other occurring virulence-associated traits were genes for adhesins, protectins/serum resistance, iron uptake and toxins: papC, iss, cvaC, kpsII, fyuA, iutA and tsh-specific virulence markers associated with extra-intestinal infection. One of the explanations for their occurrence in milk and dairy products could be the possibility of udder infection (pre/sub-clinical mastitis) [34].

Of the adhesion- and iron uptake-encoding virulence factors included in our study, the papC and fyuA genes were the most frequent. We found 11 E. coli harbouring papC (P fimbria), a gene which has been associated with upper urinary tract infection [35], and in some isolates was associated with some of the genes under investigation in this study: iss, cvaC, kpsII, st $x 1$ and/or st $x 2$. A combination of P fimbria and Shiga-toxins could be interesting due to the possibility of their causing problems related to urinary tract infection and HUS. Eleven of our isolates expressed fyuA (ferric yersiniabactin uptake), a type of siderophore, which was originally detected in Yersinia pestis, and contributes to the pathogenicity of UPEC, especially during colonization of the urinary tract. Yersiniabactin may protect bacterial cells against the host immune response [36]. The most important ColV and ColBM virulence plasmids associated with ExPEC virulence includes the aerobactin (iut $A$ /iuc $A B C D$ ). This operon encodes high-affinity iron-transport systems, which are used by bacteria to obtain iron in low-iron conditions such as those they encounter in host fluids and tissues. As many as $30 \%$ of our virulence-gene-associated isolates carried at least one siderophore gene, which allows these strains to survive in low iron environments, for example in the bladder or other host fluids and tissues.

Another gene found in the core genome of ExPEC large virulence plasmids is iss, which encodes a protein linked with increased serum survival in human $E$. coli isolates. Numerous studies have documented its strong alignment with virulent (but not with avirulent) E. coli strains [37]. Almost $16 \%$ of our virulence-gene-associated isolates exhibited a protection factor against phagocytosis, and moreover, connected either with adhesins or iron uptake genes and/or factors facilitating colonization.

No less important a role during infection is played by toxins, as they contribute to the spreading of bacteria in tissues, increased cytotoxicity and insensitivity to neutrophils. One of the most frequently detected genes encoding a toxin in ExPEC is tsh (temperaturesensitive hemagglutinin), a member of the autotransporter group of proteins first identified in avian-pathogenic Escherichia coli (APEC). Autotransporters are a family of autonomously secreted proteins from gram-negative bacteria exhibiting diverse functions involved in virulence, including adhesins, proteases, cytotoxins and cell invasion proteins. The above mentioned toxin contributes to the development of lesions and deposition of fibrin in avian air sacs. It can act both as an adhesin and as a serine protease, agglutinating erythrocytes while in contact with the extracellular surface of the bacterial cells. It can adhere to 
purified haemoglobin and bind with great efficiency to extracellular matrix proteins. It cleaves casein and exhibits mucinolytic activity [38]. This toxin was detected in $23 \%$ of our virulence-gene-associated isolates.

The important protectins/serum resistance in ExPEC involve capsula antigens kpsII (protection factor against phagocytosis and the spreading factor) and $c v a C$ (factor facilitating colonization). In our study, we found their presence together in up to $21 \%$ of our virulence-gene-associated isolates.

E. coli strains can be classified into the following phylogenetic groups: A, B1, B2, C, D, E, F, and clade I [22]. A link between the virulence of a strain and its phylogenetic group has been previously reported by Clermont et al. [22,39]. Commensal E. coli, with no pathogenic features, occurring among other places on the gastrointestinal tract mucosa, most often represent group A or B1. Pathogenic E. coli responsible for intestinal infections represent phylogenetic groups A, B1 or D. E. coli responsible for extra-intestinal infections belong in groups B2 and D. Group E is related to group D (including O157: H7), while group $\mathrm{F}$ is related to the main group B2. Clones of E. coli strains, which are genetically diverse but phenotypically indistinguishable, have been assigned to cryptic clade I [40,41].

The phylogenetic grouping examined by us showed that most $E$. coli isolates belonged in groups $\mathrm{B} 1$ and $\mathrm{A}$, followed by strains belonging in group $\mathrm{D}$, while groups $\mathrm{E}$ and $\mathrm{F}$ occurred infrequently as shown in Table 2. Our results are in agreement with those reported by Rúgeles et al. and Ombarak et al. [2,42], in which E. coli isolated from foods mainly belonged in A and B1 phylogenetic groups. The potentially virulent strains (43 strains) were mostly classified into phylogenetic group E (100\%), followed by group $\mathrm{F}(75 \%)$, group $\mathrm{D}(67 \%)$, group B1 (55\%), group C (38.5\%) and group A (27.6\%) (Table 3$)$.

\section{Conclusions}

Our obtained data suggest that $E$. coli contaminating our cheese products might have the potential for causing intestinal and, moreover, extra-intestinal infections. Although our study consists of a relatively small number of samples and therefore faces limitations in statistical analysis, it provides important information about the phylogenetic background and incidence of virulent $E$. coli isolated from cheese produced from unpasteurized ovine milk in the Slovak Republic. Our results clearly suggest that microbial quality and safety of unpasteurized cheese made from raw ovine milk produced by local farmers and distributors are not sufficiently good. The presence of coliform bacteria in raw milk products indicates not only poor hygiene, but even worse, these microorganisms are vehicles for virulent genes with the potential to cause a variety of intestinal and extra-intestinal diseases in consumers. As a relatively large number of people still consume raw milk and raw milk products, we would emphasize the increased need for food control and ensuring improved hygiene, thereby contributing to the reduction of potential public health threats.

Author Contributions: Conceptualization, D.B. and V.K.; methodology, L.K.; writing-original draft preparation, D.B. and L.K.; writing-review and editing, D.B. and L.K.; supervision, D.B. and V.K.; project administration, D.B.; funding acquisition, D.B. All authors have read and agreed to the published version of the manuscript.

Funding: This research was funded by VEGA, grant number $2 / 0010 / 21$. The APC was funded by VEGA, grant number 2/0010/21.

Acknowledgments: The authors thank Martin Tomáška from Dairy Research Institute in Žilina for providing laboratory support for sample collection.

Conflicts of Interest: The authors declare no conflict of interest.

\section{References}

1. Oliver, S.P.; Jayarao, B.M.; Almeida, R.A. Foodborne Pathogens in Milk and the Dairy Farm Environment: Food Safety and Public Health Implications. Foodborne Pathog. Dis. 2005, 2, 115-129. [CrossRef] [PubMed]

2. Ombarak, R.; Hinenoya, A.; Awasthi, S.P.; Iguchi, A.; Shima, A.; Elbagory, A.; Yamasaki, S. Prevalence and pathogenic potential of Escherichia coli isolates from raw milk and raw milk cheese in Egypt. Int. J. Food Microbiol. 2016, 221, 69-76. [CrossRef] [PubMed] 
3. Yoon, Y.; Lee, S.; Choi, K.-H. Microbial benefits and risks of raw milk cheese. Food Control 2016, 63, 201-215. [CrossRef]

4. Ioanna, F.; Quaglia, N.C.; Storelli, M.; Castiglia, D.; Goffredo, E.; Storelli, A.; De Rosa, M.; Normanno, G.; Jambrenghi, A.C.; Dambrosio, A. Survival of Escherichia coli O157:H7 during the manufacture and ripening of Cacioricotta goat cheese. Food Microbiol. 2018, 70, 200-205. [CrossRef] [PubMed]

5. Cancino-Padilla, N.; De Chile, P.U.C.; Fellenberg, M.A.; Franco, W.; Ibáñez, R.A.; Vargas-Bello-Pérez, E. Foodborne bacteria in dairy products: Detection by molecular techniques. Cienc. E Investig. Agrar. 2017, 44, 215-229. [CrossRef]

6. Gill, A.; Oudit, D.; Alexander, P. Enumeration of Escherichia coli O157 in Outbreak-Associated Gouda Cheese Made with Raw Milk. J. Food Prot. 2015, 78, 1733-1737. [CrossRef]

7. Mccollum, J.T.; Williams, N.J.; Beam, S.W.; Cosgrove, S.; Ettestad, P.J.; Ghosh, T.S.; Kimura, A.C.; Nguyen, L.; Stroika, S.G.; Vogt, R.L.; et al. Multistate Outbreak of Escherichia coli O157:H7 Infections Associated with In-Store Sampling of an Aged Raw-Milk Gouda Cheese, 2010. J. Food Prot. 2012, 75, 1759-1765. [CrossRef]

8. Kaper, J.B.; Nataro, J.P.; Mobley, H. Pathogenic Escherichia coli. Nat. Rev. Genet. 2004, 2, 123-140. [CrossRef]

9. Bielaszewska, M.; Mellmann, A.; Zhang, W.; Köck, R.; Fruth, A.; Bauwens, A.; Peters, G.; Karch, H. Characterisation of the Escherichia coli strain associated with an outbreak of haemolytic uraemic syndrome in Germany, 2011: A microbiological study. Lancet Infect. Dis. 2011, 11, 671-676. [CrossRef]

10. Dallman, T.; Cross, L.; Bishop, C.; Perry, N.; Olesen, B.; Grant, K.A.; Jenkins, C. Whole Genome Sequencing of an Unusual Serotype of Shiga Toxin-producingEscherichia coli. Emerg. Infect. Dis. 2013, 19, 1302-1304. [CrossRef]

11. Brussow, H.; Canchaya, C.; Hardt, W.-D. Phages and the Evolution of Bacterial Pathogens: From Genomic Rearrangements to Lysogenic Conversion. Microbiol. Mol. Biol. Rev. 2004, 68, 560-602. [CrossRef]

12. Costanzo, N.; Ceniti, C.; Santoro, A.; Clausi, M.T.; Casalinuovo, F. Foodborne Pathogen Assessment in Raw Milk Cheeses. Int. J. Food Sci. 2020, 2020, 3616713. [CrossRef]

13. O'Loughin, E. Escherichia coli O157:H7. Lancet 1997, 349, 1553. [CrossRef]

14. European Food Safety Authority and European Centre for Disease Prevention and Control (EFSA and ECDC). The European Union summary report on trends and sources of zoonoses, zoonotic agents and food-borne outbreaks in 2017. EFSA J. 2018, 16, e05500. [CrossRef]

15. Aslam, M.; Toufeer, M.; Bravo, C.N.; Lai, V.; Rempel, H.; Manges, A.; Diarra, M.S. Characterization of Extraintestinal Pathogenic Escherichia coli isolated from retail poultry meats from Alberta, Canada. Int. J. Food Microbiol. 2014, 177, 49-56. [CrossRef]

16. Nordstrom, L.; Liu, C.M.; Price, L.B. Foodborne urinary tract infections: A new paradigm for antimicrobial-resistant foodborne illness. Front. Microbiol. 2013, 4, 29. [CrossRef] [PubMed]

17. Johnson, J.R.; Russo, T.A. Extraintestinal pathogenic Escherichia coli: “The other bad E. coli”. J. Lab. Clin. Med. 2002, 139, 155-162. [CrossRef] [PubMed]

18. Singer, R.S. Urinary tract infections attributed to diverse ExPEC strains in food animals: Evidence and data gaps. Front. Microbiol. 2015, 6, 28. [CrossRef] [PubMed]

19. Altalhi, A.D.; Hassan, S. Bacterial quality of raw milk investigated by Escherichia coli and isolates analysis for specific virulencegene markers. Food Control 2009, 20, 913-917. [CrossRef]

20. Paneto, B.; Schocken-Iturrino, R.; Macedo, C.; Santo, E.; Marin, J. Occurrence of toxigenic Escherichia coli in raw milk cheese in Brazil. Arq. Bras. Med. Vet. Zootec. 2007, 59, 508-512. [CrossRef]

21. Bessède, E.; Angla-Gre, M.; Delagarde, Y.; Hieng, S.S.; Menard, A.; Mégraud, F. Matrix-Assisted laser-desorption/ionization BIOTYPER: Experience in the routine of a University hospital. Clin. Microbiol. Infect. 2011, 17, 533-538. [CrossRef] [PubMed]

22. Clermont, O.; Christenson, J.K.; Denamur, E.; Gordon, D.M. The ClermontEscherichia coliphylo-typing method revisited: Improvement of specificity and detection of new phylo-groups. Environ. Microbiol. Rep. 2012, 5, 58-65. [CrossRef] [PubMed]

23. Lescat, M.; Clermont, O.; Woerther, P.L.; Glodt, J.; Dion, S.; Skurnik, D.; Djossou, F.; Dupont, C.; Perroz, G.; Picard, B.; et al. CommensalEscherichia colistrains in Guiana reveal a high genetic diversity with host-dependant population structure. Environ. Microbiol. Rep. 2012, 5, 49-57. [CrossRef] [PubMed]

24. Johnson, J.R.; Stell, A. Extended Virulence Genotypes of Escherichia coli Strains from Patients with Urosepsis in Relation to Phylogeny and Host Compromise. J. Infect. Dis. 2000, 181, 261-272. [CrossRef] [PubMed]

25. Ewers, C.; Kießling, S.; Wilking, H.; Kiebling, S.; Alt, K.; Antáo, E.-M.; Laturnus, C.; Diehl, I.; Glodde, S.; Homeier, T. Avian pathogenic, uropathogenic, and newborn meningitis-causing Escherichia coli: How closely related are they? Int. J. Med. Microbiol. 2007, 297, 163-176. [CrossRef] [PubMed]

26. Le Bouguenec, C.; Archambaud, M.; Labigne, A. Rapid and specific detection of the pap, afa, and sfa adhesin-encoding operons in uropathogenic Escherichia coli strains by polymerase chain reaction. J. Clin. Microbiol. 1992, 30, 1189-1193. [CrossRef] [PubMed]

27. Dozois, C.M.; Dho-Moulin, M.; Brée, A.; Fairbrother, J.M.; Desautels, C.; Curtiss, R. Relationship between the Tsh Autotransporter and Pathogenicity of Avian Escherichia coli and Localization and Analysis of the tsh Genetic Region. Infect. Immun. 2000, 68, 4145-4154. [CrossRef]

28. Pass, M.A.; Odedra, R.; Batt, R.M. Multiplex PCRs for Identification of Escherichia coli Virulence Genes. J. Clin. Microbiol. 2000, 38, 2001-2004. [CrossRef]

29. Holko, I.; Bisova, T.; Holkova, Z.; Kmet, V. Virulence markers of Escherichia coli strains isolated from traditional cheeses made from unpasteurised sheep milk in Slovakia. Food Control 2006, 17, 393-396. [CrossRef] 
30. Skočková, A.; Koláčková, I.; Kubelová, M.; Karpíšková, R. Shiga toxin-producing Escherichia coli (STEC) in the Czech Re-public: Characterization of pathogenic strains isolated from pig and cattle carcasses. J. Food Nutr. Res. 2017, 56, 362-371.

31. Friedrich, A.W.; Bielaszewska, M.; Zhang, W.; Pulz, M.; Kuczius, T.; Ammon, A.; Karch, H. Escherichia coli Harboring Shiga Toxin 2 Gene Variants: Frequency and Association with Clinical Symptoms. J. Infect. Dis. 2002, 185, 74-84. [CrossRef] [PubMed]

32. Panel, E.B.; Koutsoumanis, K.; Allende, A.; Alvarez-Ordóñez, A.; Bover-Cid, S.; Chemaly, M.; Davies, R.; De Cesare, A.; Herman, L.; Hilbert, F.; et al. Pathogenicity assessment of Shiga toxin-producing Escherichia coli (STEC) and the public health risk posed by contamination of food with STEC. EFSA J. 2020, 18. [CrossRef]

33. Morabito, S. Pathogenic Escherichia Coli: Molecular and Cellular Microbiology; Caister Academic Press: Norfolk, VA, USA, 2014; ISBN 9781908230379.

34. Farrokh, C.; Jordan, K.; Auvray, F.; Glass, K.; Oppegaard, H.; Raynaud, S.; Thevenot, D.; Condron, R.; De Reu, K.; Govaris, A.; et al. Review of Shiga-toxin-producing Escherichia coli (STEC) and their significance in dairy production. Int. J. Food Microbiol. 2013, 162, 190-212. [CrossRef]

35. Guzman-Hernandez, R.; Contreras-Rodriguez, A.; Hernandez-Velez, R.; Perez-Martinez, I.; Lopez-Merino, A.; Zaidi, M.B.; Estrada-Garcia, T. Mexican unpasteurised fresh cheeses are contaminated with Salmonella spp., non-O157 Shiga toxin producing Escherichia coli and potential uropathogenic E. coli strains: A public health risk. Int. J. Food Microbiol. 2016, 237, 10-16. [CrossRef] [PubMed]

36. Garénaux, A.; Caza, M.; Dozois, C.M. The Ins and Outs of siderophore mediated iron uptake by extra-intestinal pathogenic Escherichia coli. Veter. Microbiol. 2011, 153, 89-98. [CrossRef]

37. Sarowska, J.; Futoma-Kołoch, B.; Jama-Kmiecik, A.; Frej-Madrzak, M.; Ksiazczyk, M.; Bugla-Ploskonska, G.; Choroszy-Krol, I. Virulence factors, prevalence and potential transmission of extraintestinal pathogenic Escherichia coli isolated from different sources: Recent reports. Gut Pathog. 2019, 11, 1-16. [CrossRef]

38. Kostakioti, M.; Stathopoulos, C. Functional Analysis of the Tsh Autotransporter from an Avian Pathogenic Escherichia coli Strain. Infect. Immun. 2004, 72, 5548-5554. [CrossRef]

39. Clermont, O.; Bonacorsi, S.; Bingen, E. Rapid and Simple Determination of the Escherichia coli Phylogenetic Group. Appl. Environ. Microbiol. 2000, 66, 4555-4558. [CrossRef]

40. Köhler, C.-D.; Dobrindt, U. What defines extraintestinal pathogenic Escherichia coli? Int. J. Med. Microbiol. 2011, 301, 642-647. [CrossRef]

41. Tivendale, K.; Logue, C.M.; Kariyawasam, S.; Jordan, D.; Hussein, A.; Li, G.; Wannemuehler, Y.; Nolan, L.K. Avian-Pathogenic Escherichia coli Strains Are Similar to Neonatal Meningitis E. coli Strains and Are Able To Cause Meningitis in the Rat Model of Human Disease. Infect. Immun. 2010, 78, 3412-3419. [CrossRef]

42. Rúgeles, L.C.; Bai, J.; Martínez, A.J.; Vanegas, M.C.; Gómez-Duarte, O.G. Molecular characterization of diarrheagenic Escherichia coli strains from stools samples and food products in Colombia. Int. J. Food Microbiol. 2010, 138, 282-286. [CrossRef] [PubMed] 